\title{
KRISTOLOGI BIBLIKA MENURUT KAUM REFORMED SEBAGAI SALAH SATU DASAR APOLOGETIKA DALAM MENGHADAPI PENGAJARAN GNOSTIK DI ERA POSTMODERN
}

\author{
Abstrak
}

Kristologi adalah merupakan pokok terpenting dalam ajaran iman Kristen. Kristologi juga bisa disebut sebagai pusat kekristenan itu sendiri, dengan itu kristologi adalah pusat dari ilmu theologia. Karenanya mempelajari Pribadi dan karya Kristus, berarti sedang berada pada pusat theologi Kristen. Yesus Kristuslah yang memberikan identitas kepada kekristenan, yang sekaligus membedakannya dari agama atau kepercayaan yang lain. Keistimewaan doktrin ini terletak dalam pribadi dan karya Yesus Kristus sebagai Tuhan yang menjadi finalitas jalan menuju kepada keselamatan yang kekal.

Pemahaman yang benar terhadap doktrin kristologi tidak lepas dari pengetahuan yang sehat terhadap Alkitab, sebab Alkitablah satu-satunya sumber utama yang dengan jujur dan terbuka memberikan kesaksian mengenai pribadi Yesus sebagai juruselamat dunia. Memang realita historis tulisan-tulisan di dalam Alkitab itu ditulis oleh manusia, akan tetapi proses penulisannya diilhami oleh Allah melalui pimpinan Roh Kudus sehingga apa yang diucapkan atau ditulis sesuai dengan kehendak Tuhan (bnd. 2Tim 3:16). Alkitab secara keseluruhan dipercaya dengan akurat dalam mengambarkan Yesus Kristus. Akan tetapi dalam prosesnya banyak ditemukan bahwa kristologi yang dihasilkan bertentangan dengan Alkitab. Sejarah membuktikan bahwa gereja selalu berhadapan dengan pengajaran-pengajaran sesat yang menyerang gereja 
dari dalam. dalam ini berbentuk ajaran-ajaran (doktrin) yang menyesatkan atau bidat-bidat yang menyelewengkan ajaran murni Alkitab. Bahaya ajaran-ajaran sesat ini tidak saja timbul pada abad-abad belakangan ini, melainkan sudah ada sejak gereja didirikan. Karenanya penulis hendak menguraikan kristologi yang akan menjadi dasar apologetika di era postmodern sekarang ini.

\section{BAB I PENDAHULUAN}

Dari semua uraian di atas dapat ditarik kesimpulan bahwa hanya Alkitab yang bisa diterima sebagai sumber kebenaran yang memberikan kesaksian tentang Yesus Kristus sebagai juruselamat satu-satunya. Atau dengan kata lain di dalam upaya berteologi (kristologi), dituntut untuk dapat menghasilkan teologi yang Alkitabiah yang dibangun di atas dasar Alkitab, Firman Allah.

Realita itu dengan jelas terlihat dalam Alkitab bahwa pada jaman rasul-rasul, gereja yang masih muda usia sudah harus bergumul melawan ajaran-ajaran yang menyesatkan (bnd. Kis. 15:111; Gal. 5:2-6). Dengan cara demikian, para rasul meneguhkan orang-orang percaya dengan menuliskan surat. 
Pengajaran yang menyimpang itu tidak saja berkembang begitu saja, tetapi sejarah mencatat bahwa mengalami perkembangan dari abad ke abad. Dari sekian banyak bidat yang ada di dalam gereja salah satu yang muncul pada abad ke-2 adalah bidat Gnostik. Kata "Gnostik" berasal dari kata Yunani "gnosis" yang berarti pengetahuan. Istilah "Gnostik" secara khusus dipakai sebagai sebutan bagi beberapa "aliran kepercayaan" pada abad ke-2. Tokoh-tokoh dan para penganut mazhab Gnostik ini menyatakan bahwa mereka mempunyai pengetahuan (gnosis) yang lama dan yang lebih tinggi dari pada iman Kristen, seperti yang dianut oleh anggota jemaat biasa. Iman yang dimiliki oleh jemaat biasa adalah pengungkapan kasar dari kebenaran yang dinyatakan jauh lebih sempurna dalam ajaran Gnostik. Pokok-pokok utama dalam ajaran ini ialah asal dunia, tabiat manusia; dan yang utama, asal kejahatan. ${ }^{1}$

Mengenai dunia, gnostik meyakini diciptakan oleh suatu ilah rendah (namanya "demiurgos", artinya pencipta dunia), yang dikenal dari Perjanjian Lama. Kemudian membagi kosmos menjadi dua bagian, yang mana bagian pertama adalah bagian dunia rohani (yang tidak nampak) yang merupakan dunia yang baik, tempat akhir manusia. Dan yang kedua adalah bagian dunia materi (yang nampak), merupakan dunia yang jahat dan fana. Sementara mengenai manusia, gnostik membagi dalam tiga bagian yaitu roh, jiwa, dan tubuh. Orang yang bersifat tubuh (dunia) tidak akan memperoleh keselamatan, hanya mereka yang bersifat rohani diselamatkan karena mereka memiliki pengetahuan, ${ }^{2}$ sedangkan orang yang bersifat jiwani hanya diselamatkan melalui percikan dari keilahian yang terkurung dalam tubuh. ${ }^{3}$

\footnotetext{
${ }^{1}$ Th. van den End, Harta dalam Bejana, (Jakarta: BPK Gunung Mulia, 1999), 35

${ }^{2}$ Paulus Daun, Bidat Kekristenan, ..., 75

${ }^{3}$ A. F Walls, add all, "Gnostik", J.D Douglas, Ensiklopedi Alkitab Masa Kini, (Jakarta: Yayasan Komunikasi Bina Kasih, 2008), 344
} 
Pada umumnya bidat ini terdiri dari berbagai kepercayaan dengan dasar pandangan yang sama yaitu keselamatan dicapai dengan jalan pengetahuan rahasia. ${ }^{4}$ Dengan demikian, biasa dikatakan adalah percampuran antara agama timur dengan agama barat yang merupakan sinkritisme yang dualistis-panteistis. Paulus Daun menegaskan :

Ajaran gnostik ini bersumber dari pencampuran antara agama timur, yaitu agama Mesir yang menyembah dewi Isis dan dewa Osiris, agama Siria yang menyembah dewa Baal, agama Persia menyembah dewa Mitras dan agama Asia yang menyembah dewa Kibele ; dan filsafat barat, yaitu ; pikiran filsafat plato tentang dunia "idea" dan ditambah lagi konsep pemikiran tentang keselamatan dari agama Kristen. Dengan demikian, wujud gnostisisme pada hakikatnya adalah sinkritisme yang dualismepanteistis. ${ }^{5}$

Selain uraian di atas, sifat umum dari gnostik adalah pengetahuan, dimana keselamatan meliputi penyucian dan kekekalan dengan pertalian pada konsep filsafat, mitologi, atau astrologi yang kontemporer, mengajarkan adanya pemisahan mutlak dengan Allah dari zat (Yunani : pembawaan jahat) diterima, dan drama penyelamatan diperankan oleh banyak makhluk perantara. ${ }^{6}$ Maka bisa disimpulkan bahwa gnostik mengajarkan bahwa Allah tidak berhubungan dengan materi/zat.

Dewasa ini pergerakan gnostisisme berkisar pada isu-isu ketidakpuasan terhadap Yesus yang diimani melalui cerita Alkitab hingga penolakan kepada Yesus sebagai finalitas penyataan Allah. Gerakan gnostisisme ini diawali oleh suatu gerakan yang dikenal dengan nama "The Quest" (gugatan) pada era modern. Gugatan tersebut dibedakan dalam empat periode, yaitu: pertama, "The Quest" melalui tulisan Strauss, Renan, dan Schweitzer, serta beberapa pemikiran teolog kontemporer lainnya; kedua, "The New Quest" yang dirintis oleh Ernst Kasemann dan gerakan Jesus Seminar yang membandingkan Injil Kanonik dengan Injil Thomas; ketiga, "The Third

\footnotetext{
${ }^{4}$ F. D Wellem, Kamus Sejarah Gereja, (Jakarta: BPK Gunung Mulia, 1994), 78

${ }^{5}$ Paulus Daun, Bidat Kekristenan, ..., 74

${ }^{6}$ A. F Walls, add all, "Gnostik", J.D Douglas, Ensiklopedi,..., 344
} 
Quest" dengan tokoh-tokohnya, seperti Marcus Borg, E.P. Sander, dan James D.G. Dunn; dan keempat, "The Never Ending Quest", yaitu dengan banyaknya pandangan kontroversial yang muncul, baik melalui buku-buku, jubah kain ilmiah, novel populer, maupun film. ${ }^{7}$

Memasuki era postmodern gugatan ini kembali muncul, sebagaimana yang dituliskan Herlianto :

Pada tahun 2003 terbit sebuah buku novel yang kemudian difilmkan, yang berjudul The Da Vinci Code. Buku ini laris manis dan sudah diterjemahkan ke dalam puluhan bahasa, termasuk bahasa Indonesia. Novel ini melontarkan isu, bahwa Ketuhanan Yesus diresmikan melalui voting oleh Kaisar Konstantinus dalam Konsili Nicea (325) dan bahwa Yesus mengawini Maria Magdalena serta memiliki keturunan yang tinggal di Perancis/Inggris. Demikian juga dengan Gereja Katolik Roma yang dituduh telah mendirikan suatu organisasi awam, Opus Dei, untuk membungkam bukti mengenai adanya keturunan Yesus. Di samping itu, organisasi ini juga menonjolkan organisasi fiktif, Priore de Sion, yang bersifat sebaliknya, yaitu ingin menjaga keturunan suci itu. $^{8}$

Dari uraian di atas, jelas bahwa isu dalam novel itu tidak benar dan menyimpang dari doktrin kristologi yang biblika.

Selain itu, masalah karya kebangkitan Yesus banyak para teolog yang tidak puas dengan sumber alkitabiah, maka dengan itu mereka membutuhkan catatan sejarah, temuan arkeologis, pembuktian DNA, analisis lewat metode Carbon 14, dan lain-lain. Setelah itu baru mereka percaya akan kebangkitannya. ${ }^{9}$ Jadi, para teolog mencoba berusaha membuktikan kebangkitan Yesus dengan alasan-alasan rasional yang bisa diterima di era masa kini.

Ketidakpuasan kepada Yesus tidak berhenti sampai di situ, para teolog terus mencari Yesus 'yang lain' sebagai upaya memperkaya acuan berteolog meskipun tidak seperti yang digambarkan oleh Alkitab. Seperti halnya disampaikan oleh Berghouser B, dalam sebuah artikel akademisi bahwa :

\footnotetext{
${ }^{7}$ Herlianto, Menggugat Yesus, (Bandung: Yayasan Kalam Hidup, 2008), 12

${ }^{8}$ Ibid, 13

${ }^{9}$ Horald Lolowang, Yesus Nazaret vs Yesus Makam Talpiot, (Yogyakarta: ANDI, 2008), 269
} 
Pencarian Yesus 'yang lain' akan juga memberikan paradigma berteologi yang lain pula. Ia tidak lagi harus persis seperti yang digambarkan oleh Alkitab, mengingat Alkitab sendiri terbatas pada penggambaran atau kesaksian kalangan Kristen. Adalah benar bahwa di dalamnya terdapat unsur historisitas yang kuat, namun bukan pula berarti Alkitab sumber sejarah yang akurat dari Yesus itu sendiri. Alkitab bagaimana pun, bukanlah sebuah biografi ataupun catatan sejarah Yesus dari Nazaret. Oleh sebab itu, sebuah pengambaran 'yang lain', dalam hal ini Yesus Sejarah, patut mendapat perhatian pula. Tidak perlu langsung ditentang, dituduh menghujat, bahkan menyesatkan, melainkan harus dipahami bahwa pencarian tersebut secara tidak sadar turut memberikan banyak arti bagi iman Kristen dewasa ini. Pencarian yang demikian bahkan akan sangat menguatkan dan menegaskan iman Kristen yang berakar dalam zaman dan sejarah dunia. ${ }^{10}$

Hal lain gerakan gnostik menampakkan wujudnya dengan kebangkitan Gerakan Zaman Baru (New Age). ${ }^{11}$ Salah satu artikel menjelaskan dan memuji praktik-praktik dan kepercayaankepercayaan yang berada di luar kekristenan tradisional, dan yang biasanya dikaitkan dengan aspek-aspek pemikiran Zaman Baru, seperti meditasi Zen, para psikologi, dan agama "dewi" (Goddess). Adapun tokoh-tokoh yang populer dalam hal "spiritualitas baru" ini adalah Anand Khrisna dan Deepak Chopra, walaupun masih banyak tokoh-tokoh lainnya, tapi kedua orang ini adalah tokoh yang sangat populer, baik di Amerika maupun di Indonesia. ${ }^{12}$

Contoh-contoh ini menjadi ancaman yang sangat berbahaya didalam kekristenan, sebab masalah ini bisa mengacaukan pemahaman para pengikut Yesus dan membawa kepada penyesatan. Kaum gnostik era postmodern berusaha merekonstruksi doktrin kristologi yang baru berdasarkan sumber-sumber yang dianggap otentik. Mereka dengan berbagai upaya menggoyahkan dan merobohkan doktrin yang ortodoks.

Melihat realita ini harusnya Alkitab yang menjadi pedoman utama bagi para teolog sebagai dasar membangun doktrin terhadap pribadi Yesus. Stevri I. Lumintang menyatakan bahwa:

${ }^{10}$ Berghouser B, "Beriman Pada Yesus Yang Lain”, Jurnal Teologia Proklamasi edisi 02, (Jakarta: STTJ, 2002), 67

${ }^{11}$ Suatu gerakan yang dalam banyak segi mengambil tema-tema Kristen, tetapi dengan pengertian yang berbeda.

${ }^{12}$ Douglas Groothuis, Yesus di Zaman Kontroversi, (Jakarta: Verbum Dei Books, 2008), 73 
"teologia kekristenan begitu unggul karena semata-mata hanya karena Firman Allah (Alkitab).

Firman Allah yang diinspirasi oleh Roh Kudus kepada para penulis sehingga tidak mungkin salah". ${ }^{13}$

Hal inilah yang mendorong penulis untuk menuangkannya dalam sebuah karya tulis yang berjudul : Kristologi Biblika Menurut Kaum Reformed Sebagai Dasar Apologetika dalam Menghadapi Pengajaran Gnostik di Era Postmodern. Dengan satu keyakinan bahwa konsep kristologi biblika menurut kaum Reformed mampu mengokohkan, meneguhkan serta membentengi para teolog dan juga orang percaya dalam menghadapi ancaman gnostik pada era postmodern.

\section{BAB II}

\section{KRISTOOGI BIBLIKA MENURUT KAUM REFORMED}

Mengenai Reformed Harvie M. Conn mengutip pernyataan Runia bahwa asal mula kata "Reform" menyatakan ciri gereja-gereja pada abad 16 yang bangkit untuk memprotes kekeliruankekeliruan dan penyimpangan-penyimpangan yang menguasai Gereja Katolik Roma pada abad pertengahan. Dalam arti luas, istilah ini dapat dikenakan kepada semua gereja Reformasi karena mereka semua menganut satu tujuan yaitu hidup menurut Firman Allah, baik dalam lingkup luas kehidupan gereja, maupun dalam lingkup pribadi kehidupan orang percaya. ${ }^{14}$ Jadi, teologia

\footnotetext{
${ }^{13}$ Stevri I. Lumintang, Keunikan Teologi Kristen di Tengah Kepalsuan, (Batu: Literatur YPPII, 2010), 129

${ }^{14}$ Harvie M. Conn, Teologia Kontemporer, (Malang: Literatur SAAT, 1990), 168
} 
Reformed adalah teologia yang berusaha menperhatikan semua kekeliruan terhadap pengajaranpengajaran yang menyimpang di tengah-tengah gereja, dan mengembalikan kepada Alkitab sebagai dasar yang benar.

\section{Hakikat Kristologi Menurut Kaum Reformed}

Ada pun yang mendasari kristologi bagi kaum Reformed adalah berakar dari kristologi ortodoks, kristologi yang bersumber dari Alkitab, serta mengakui Yesus sebagai wahyu Allah sebagai final.

\section{Kristologi Kaum Reformed Berakar dari Kristologi Ortodoks}

Theologia Reformed bukanlah suatu jenis theologia yang baru, melainkan suatu theologia yang telah berakar pada theologia gereja mula-mula, yaitu theologia yang disebut orthodoks atau tradisional, yang kemudian ditegaskan ulang oleh para reformator dan dijadikan dasar berpijak oleh theolog Injili masa kini. ${ }^{15}$ Teologi Reformed (Reformed Theology) disebut juga sebagai penganut Calvinisme. Searah dengan itu Lumintang menjelaskan bahwa :

Kaum Reformed pada hakikatnya mengikuti teologi John Calvin, secara khusus mengikuti prinsip-prinsip dasar teologi Calvin dan teori para teolog lainnya yang mendukung teologi Calvin, termasuk pemikiran-pemikiran para reformator sebelum Calvin, yang memiliki kesamaan prinsip dasar teologi dengan Calvin, misalnya Luther yang banyak mempengaruhi Calvin. ${ }^{16}$

Dari uraian di atas dapat ditarik kesimpulan bahwa teologi Reformed adalah teologia yang berakar dari pemikiran serta dipelopori oleh Calvin. Dengan itu, seperti yang dijelaskan sebelumnya bahwa theologia Calvin berakar dari pokok-pokok pemikiran teolog yang ortodoks.

\footnotetext{
${ }^{15}$ Stevri I. Lumintang, Theologia \& Misiologia Reformed, (Batu: Literatur PPII), 41

${ }^{16}$ Ibid, 532
} 


\section{Kristologi Reformed Bersumber dari Alkitab}

Mengenai prinsip dasar teologia reformed, Stevri I. Lumintang menjelaskan bahwa teologi Reformed adalah teologi yang kekuatannya, bukan terletak pada pembahasannya, warna teologinya dan kemampuan teologinya, melainkan terletak pada sumber teologi tersebut yaitu Alkitab (Sola Scriptura). ${ }^{17}$ Jadi, landasan teologi dari kaum Reformed adalah bersumber dari Alkitab.

Lebih lanjut lagi Lumintang mengutip pernyataan R.W.A Letham dalam bukunya Introduction to the Reformed Tradition, yang mengatakan bahwa karakteristik teologia Reformed adalah : Pertama, sentralitas Allah atau teologi theosentris adalah tema sentral teologi Reformed, bahwa penyataan diri Allah dalam kitab suci adalah berfokus pada Allah Tritunggal, dan Yesus Kristus sebagai penyataan final Allah, sebagai mediator satu-satunya. Kedua, Kristo-sentrisitas adalah merupakan penekanan kaum Reformed dalam berteologi, sebab bagi Reformed seluruh Alkitab berpusat pada Kristus. Ketiga, teologi Reformed adalah teologi Pluriformity, artinya teologi yang bukan dan tidak pernah menjadi teologi yang monolithic. Karena teologi Reformed telah memiliki kecukupan vitalitas yang kreatif untuk menunjukan arah bagi perbedaan-perbedaan dalam semua consensus kaum Reformed. ${ }^{18}$ Karena itu sangat jelas bahwa kristologi Reformed dibangun di atas Alkitab.

\section{Kristologi Reformed Meyakini Yesus Sebagai Finalitas Wahyu Allah}

\footnotetext{
${ }^{17}$ Stevri I. Lumintang, Theologia \& Misiologi, ..., 42

${ }^{18}$ Ibid, 533
} 
Kaum Reformed mengakui bahwa Yesus Kristus itu sendiri adalah wahyu Allah. Para penulis kitab dari seluruh Alkitab adalah mediasi Allah. Yesus Kristus yang ditulis oleh para penulis Alkitab adalah wahyu itu sendiri. Yesus adalah wahyu khusus yang dinyatakan setelah wahyu umum (penciptaan), sebab wahyu umum tidak dapat memfasilitasi manusia mengenal Allah, dan tidak ada dari ciptaan manusia yang dapat mengatasi dosa. Yesus Kristuslah yang dapat mewujudkan kedua maksud tersebut. ${ }^{19}$

Keunggulan teologia Reformed sangat menekankan penyataan atau wahyu Allah karena diyakini sebagai sumber pengetahuan yang benar. Akan tetapi manusia tidak dapat mengerti wahyu umum tanpa wahyu khusus. Dalam wahyu umum, manusia dimungkinkan menemukan ilmu pengetahuan, namun ilmu pengetahuan tersebut tidak akan mencapai titik sasaran terakhir kecuali dimengerti berdasarkan wahyu khusus. Itulah sebabnya teologia Reformed menegaskan bahwa ilmu pengetahuan harus ditaklukkan kembali kepada Allah di dalam Kristus. ${ }^{20}$ Dengan itu sangat jelas bahwa pengetahuan terhadap Allah hanya dapat ditemukan di dalam Kristus.

\section{Pokok-pokok Kristologi menurut kaum Reformed Kaum}

Ada pun pokok-pokok penting tentang kristologi menurut kaum Reformed antara lain : praeksistensi Kristus, kekekalan Kristus, inkarnasi Kristus, pribadi Yesus, nama-nama Yesus, jabatan-jabatan Yesus, serta karya-karya-Nya.

\footnotetext{
${ }^{19}$ Stevri I. Lumintang, Keunikan Theologia Kristen,..., 84-85

${ }^{20}$ Stephen Tong, Reformasi, ..., 87-88
} 


\section{Praeksistensi Kristus Menurut Kaum Reformed}

Menurut Charles C. Ryrie praeksistensi Kristus berarti Ia telah ada sebelum dilahirkan. Artinya Yesus telah ada jauh sebelum ada penciptaan dan sebelum adanya waktu, akan tetapi praeksistensi tidak disamakan dengan kekekalan-Nya. ${ }^{21}$ Praeksistensi dan kekekalan berbeda tetapi tak bisa dipisahkan.

Keberadaan Yesus sebelum Ia berinkarnasi (praeksistensi) dapat dibuktikan secara biblika, seperti halnya pengakuan Yesus sendiri bahwa Ia telah ada sebelum Abraham ada (Yoh. 8:58). Hal ini jelas bahwa sebelum ada karya penciptaan, Yesus telah ada, maka Yesus pun ikut terlibat dalam karya penciptaan (Yoh.1:3; Kol.1:16; Ibr. 1:2). Paulus pun menuliskan dalam Kolose 1:17 bahwa "ia ada terlebih dahulu dari segala sesuatu ada di dalam Dia". ${ }^{22}$

Selain dari bukti-bukti di atas, bukti lain adalah pernyataan-pernyataan bahwa Yesus berasal dari surga (Yoh. 3:13), memiliki hakikat yang sama dengan Allah (Yoh. 10:30), memiliki kemuliaan yang sama dengan Bapa sebelum dunia ada (Yoh. 17:5). Pengakuan Paulus juga bahwa Kristus memiliki sifat yang sama dengan Allah (Flp. 2:6). ${ }^{23}$ Dengan itu, Yesus memiliki derajat yang sama dengan Allah Bapa dan sekaligus menyatakan keberadaan (eksis) yang sama, sebelum berinkarnasi ke dunia.

\section{Kekekalan Kristus Menurut Kaum Reformed}

\footnotetext{
${ }^{21}$ Charles C. Ryrie, Teologia Dasar 1, (Yogyakarta: Yayasan ANDI, 2013), 352

${ }^{22}$ Paul Enns, The Moody Handbook of Theology, (Malang: Literatur SAAT, 2010), 264

${ }^{23}$ Charles C. Ryrie, Teologia,..., 352-354
} 
Salah satu sifat hakiki Yesus adalah bersifat kekekalan. Kekekalan yang dimaksudkan adalah Yesus tetap ada, sifatnya abadi, selama-lamanya, atau sebagai awal dan akhir. Dengan itu, aspek kekekalan Kristus harus diperhatikan dalam Alkitab sebagai kebenaran. Alkitab menyaksikan bahwa Kristus bukan saja kekal tetapi juga memiliki semua sifat-sifat ilahi Allah.

Dalam Mikha 5: 1 dituliskan bahwa Anak yang akan lahir di Betlehem adalah "permulaannya sudah sejak purbakala, sejak dahulu kala". Selain itu kedatangan Kristus juga dinyatakan secara ilahi dalam Yesaya 9:5 bahwa Kristus itu sebagai Allah yang 'perkasa'dan 'Bapa yang kekal'. Nama 'Jehova' juga sering dikenakan kepada Kristus, seperti dalam Keluaran 3:14 dinyatakan : AKULAH yang kekal". ${ }^{24}$

Sementara itu dalam PB juga memberikan kesaksian mengenai kekekalan Yesus. Secara jelas dituliskan dalam Yohanes 1:1 bahwa, "Firman itu adalah Allah" (Theos), bukan bersifat ilahi (Theois). ${ }^{25}$ Kemudian dalam surat Kolose 1:17 menegaskan bahwa, "Ia ada terlebih dahulu sebelum segala sesuatu dan segala sesuatu ada di dalam Dia”. Demikian dalam Efesus 1:4 memuat tentang janji-janji Allah yang kekal. Bahkan dalam pernyataan Yesus sendiri dalam Wahyu 1:8, 17: "Aku adalah Alfa dan Omega,..Yang Awal dan yang Akhir". ${ }^{26}$ Ini menunjukkan praeksistensi Yesus yang kekal.

Kekekalan Yesus juga dapat ditemukan dengan kesamaan hakikat dengan Allah. Charles C Ryrie menuliskan bahwa kata gambar (Yunani: karakter) dalam surat Ibrani 1:3 menunjukkan bahwa Kristus adalah wajud atau inti sifat Allah yang persis sama. ${ }^{27}$ Atribut-atribut yang dikenakan kepada Yesus juga sama dengan Allah, seperti Maha Hadir (Ul 4:39; Kis 17:27), Maha

\footnotetext{
${ }^{24}$ Charles C. Ryrie, Teologia,..., 352-354

${ }^{25}$ Ibid

${ }^{26}$ Ibid

${ }^{27}$ Ibid, 53
} 
Kuasa (Mat. 9:6; Yoh. 10:18), Maha Tahu (Yoh. 2:24, Kis. 17:27), Kudus (Luk. 1:35), dan lain sebagainya.

\section{Inkarnasi Yesus Menurut Kaum Reformed}

Istilah inkarnasi tidak ditemukan dalam Alkitab, tetapi istilah ini telah menjadi istilah yang baku (terminus teknikus) dalam tradisi berteologia. Kata inkarnasi (in carne) artinya masuk ke dalam daging. ${ }^{28}$ Istilah inkarnasi merujuk kepada pribadi kedua dari Allah Tritunggal menjadi manusia.

Rujukan inkarnasi Yesus terdapat dalam Yohanes 1:14, 'Firman itu telah menjadi manusia”. Kata manusia dalam bahasa Yunani adalah Sark, artinya daging. ${ }^{29}$ Hal ini menyatakan bahwa kesungguhan menjadi manusia, sementara Firman (Logos), menyatakan kesungguhan keilahian Yesus. Jadi inkarnasi adalah Firman (Logos) yang benar-benar Ilahi itu telah sungsuh-sungguh menjadi manusia.

Istilah lain yang berkaitan dengan inkarnasi adalah teori kenosis. Rujukan dari istilah kenosis terdapat dalam Filipi 2:7, Ia ‘mengosongkan' (ekenosen) Diri-Nya. Menurut Paul Enns pengosongan diri-Nya bukan merupakan pengurangan tetapi sebuah tambahan, dengan pendekatan bahwa pengosongan adalah mengambil rupa seorang hamba, menjadi sama dengan manusia, dan dalam rupa seorang manusia, serta Ia merendahkan diri-Nya menjadi taat sampai mati. ${ }^{30}$ Dengan itu, keilahian Yesus menjadi tidak berkurang setelah Ia menjadi manusia.

\footnotetext{
${ }^{28}$ Paul Enns, The Moody Handbook, ..., 271

${ }^{29}$ Charles C. Ryrie, Teologia Dasar I, .., 357

${ }^{30}$ Paul Enns, The Moody Handbook,..., 281
} 
Menurut Charles R. Ryrie tujuan dari inkarnasi oknum kedua Allah Trinitas adalah: sebagai bentuk penyingkapan diri Allah kepada manusia (Yoh. 1:18; 14:7-11), untuk menjadi teladan bagi umat manusia (1Ptr. 2:21; 1Yoh. 2:6), untuk memberikan pengorbanan yang efektif untuk dosa (Ibr. 10:1-10), untuk mengenapi perjanjian kepada Daud (Luk. 1:31-33). Kemudian untuk menjadi imam yang besar yang penuh rasa simpati (Ibr. 4:14-16), serta untuk menjadi seorang hakim yang memenuhi syarat (Yoh. 5:22, 27). ${ }^{31}$ Dengan itu, genaplah yang dinubuatkan oleh para nabi.

\section{Pribadi Yesus Kristus Menurut Kaum Reformed}

Alkitab menyaksikan keunikan pribadi Yesus Kristus, yaitu Allah sejati dan manusia sejati. Kedua natur ini tak bisa dipisahkan satu dengan yang lainya. Menurut kaum Reformed rumusan teologi ini menjadi pemahaman yang baku dalam iman Kristen. Dalam bagian ini penulis menguraikan kedua natur pribadi Yesus tersebut.

\section{Yesus adalah Allah Sejati}

Alkitab memberikan rujukan tentang ke-ilahian Yesus, misalnya dalam pengajaran-Nya selalu bersifat egosentris. Senada dengan itu J.R.W Stott menuliskan bahwa:

Pengajaran Yesus bersifat egosentris artinya Dia hampir selalu berbicara tentang diriNya sendiri. Meskipun Dia juga berbicara tentang Allah Bapa namun dihubungkan dengan diri-Nya yang selalu menjadi pusat beritanya. Dia juga berbicara tentang kerajaan Allah tetapi Dia juga menempatkan dir-Nya sebagai pusat kerajaan itu (Mat. 13:41; 16:23; 20:21; 25:34-40; Luk. 24:42; Yoh. 18:33-38). Dia juga menunjuk diriNya sendiri dengan berkata : Akulah jalan (Yoh. 14:6), Akulah roti hidup (Yoh. 6:35), dan seterusnya. Dia juga memprolamsikan bahwa apa yang dikatakan dalam kitab taurat, kitab nabi-nabi, dan mazmur tentang diri-Nya (Yoh. 5:46; Yoh. 8:56; Luk. 4:18-19; Luk. 24:27, 44). Bahkan Dia juga menentang pendengar-Nya secara

\footnotetext{
${ }^{31}$ Charles C. Ryrie, Teologia Dasar I..., 362-365
} 
langsung dengan berkata: "Marilah kepada-Ku" atau "ikutlah Aku" dan Dia berjanji akan mengangkat segala beban orang yang kesusahan (Mat. 11:28-30), mengenyangkan yang lapar (Yoh. 6:35), dan menyegarkan jiwa yang dahaga (Yoh. $6: 35 ; 7: 37$ ). Dia menuntut pengikut-Nya untuk percaya dan taat kepada-Nya (Yoh. $6: 29 ; 3: 36 ; 8: 24 ; 16: 8-9$ ), bahkan mengasihi-Nya lebih dari yang lain (Mat. 10:37). Kemudian juga menyatakan bahwa jika Dia telah kembali ke sorga, maka Dia akan mengutus Roh Kudus untuk bersaksi tentang Dia (Yoh. 15:26), memuliakan Dia dan memberitakan apa yang diterima dari Dia (Yoh:14:16). Akhirnya, Dia berkata : "Apabila Aku ditinggikan dari bumi, Aku akan menarik semua orang datang kepada$\mathrm{Ku}$ "(Yoh. 12:32). ${ }^{32}$

Selain dari pengajaran-Nya yang besrsifat egosentris, Yesus juga mengakui bahwa ia adalah Allah. Pemakaian kata ego emi (Akulah) juga dipakai dalam Perjanjian Lama, dimana Allah menyatakan diri-Nya kepada Musa,"Aku adalah Aku" (Kel. 3:14). Selain itu, Yesus sendiri juga mengaku bahwa Ia adalah Mesias (Mrk. 8:27-28). Keabsahan-Nya sebagai Allah juga dinyatakan melalui aktifitas yang hanya bisa dilakukan oleh Allah, seperti mengampuni dosa (Mrk. 2:1-12; Luk. 7:48), Dia memberi hidup (Yoh. 6:35; Yoh. 4:10-15, dan seterusnya), serta Dia juga akan menghakimi dunia dan mengangkat orang mati. ${ }^{33}$ Selain itu, dibuktikan dengan tindakan atau perbuatan-Nya yang melampaui rasional (irasional) manusia, yaitu mujizat. Secara moral, Yesus juga memiliki moral yang bersifat ilahi artinya Ia tidak hidup didalam dosa. Tak ada seorang pun yang membuktikan Dia berdosa (Yoh. 8:29). Dengan itu sangat jelas bahwa Yesus adalah sungguh-sungguh Allah sejati.

\section{Yesus adalah Manusia Sejati}

Selain pengakuan kepada keilahian Yesus, kaum Reformed juga mengakui bahwa Yesus adalah manusia sejati. Dalam Yohanes 1:14 sangat jelas dikatakan bahwa Firman "Logos" itu telah menjadi daging "Sark".

\footnotetext{
32 J.R.W Stott, Karya Kristus Bagi Kita, (Jakarta: BPK Gunung Mulia, 1984), 17-18

${ }^{33}$ Paul Enns, The Moody HandBook of Theology, ..., 275-278
} 
Kemanusiaan Yesus dapat dilihat dengan aspek-aspek kehidupan manusia biasa pada umumnya. Secara fisik Yesus dilahirkan oleh seorang wanita (Gal. 4:4). Akan tetapi Yesus dilahirkan dari anak dara, dengan itu Dia tidak berdosa. Yesus juga merasakan lapar (Mat. 4:2; 21:18), merasakan haus (Yoh. 19:28), Ia merasakan letih (Yoh. 4:6). ${ }^{34}$ Artinya, Yesus juga merasakan apa yang dirasakan oleh manusia pada umumnya.

selain itu, seperti manusia pada umumnya memiliki proses mental secara normal, Yesus juga demikian. Yesus harus bertanya untuk mendapatkan informasi (Mrk. 9:21; Luk. 2:46-67). Secara intelektual, Yesus juga belajar kitab suci dengan nalar sebagaimana anak-anak Yahudi pada saat itu. Secara emosional, Yesus mengasihi keluarga-Nya (Yoh. 19:26), dan sahabat-Nya (Mat. 23:37), bisa marah (Mrk. 19:26), merasakan sedih (Mat. 9:36), Ia juga memiliki kehendak yang beda dengan Bapa-Nya (Mat. 26:39). Dan secara spiritual, Yesus juga berdoa kepada Bapa (Mrk. 1:35), serta beriman dan taat kepada Bapa (Fil. 2:8). ${ }^{35}$ Dari semua uraian diatas, sangat jelas bahwa ciri-ciri manusia pada umumnya juga dimiliki oleh Yesus.

\section{Karya Yesus Kristus Menurut Kaum Reformed}

Pada bagian ini penulis akan menguraikan karya-karya Kristus yang meliputi : kelahiranNya, kematian-Nya, kebangkitan-Nya, dan kenaikan-Nya serta kedatangan-Nya kembali.

\footnotetext{
${ }^{34}$ Henry C. Thiessen, Teologia Sistematika, (Malang: Gandum Mas, 2007), 333-334

${ }^{35}$ Stevri I. Lumintang, Keunikan Theologia Kekristenan di Tengah Kepalsuan, (Malang: Literatur PPII, 2010), 88-89
} 


\section{Kelahiran-Nya}

Peristiwa sekitar kelahiran Tuhan Yesus berbeda dengan kelahiran manusia biasa pada umumnya (Mat. 1:18:25 dan Luk. 1:26-38). Sebelum kelahiran-Nya diawali dengan kedatangan malaikat Gabriel kepada Maria untuk memberitakan bahwa ia akan mengandung Mesias (Luk. 1:26). Kemudian keunikan kelahiran Yesus juga terletak pada kelahiran seorang perawan. Charles R. Ryrie menulis bahwa tujuan kelahiran seorang perawan adalah untuk menjaga agar Kristus tetap tanpa dosa. ${ }^{36}$ Dengan itu, kelahiran Yesus telah menyatakan kuasa Allah yang ajaib dalam karyaNya.

Peristiwa lain setelah kelahiran Yesus pun dinyatakan dengan kedatangan orang-orang majus dari timur, dengan membawa persembahan berupa mas, mur, dan kemenyan (Mat. 2:1-2) kepada Sang Raja Agung. Selain itu Lukas 2:8-20 mencatat bahwa malaikat Tuhan memberitakan kepada gembala-gembala yang tinggal di padang mengenai kelahiran Sang Juru Selamat, Kristus Yesus. Peristiwa-peristiwa sekitar kelahiran Yesus merupakan karya agung sebagai rahasia Allah yang dinyatakan pada umat manusia.

\section{Kematian-Nya}

\footnotetext{
${ }^{36}$ Charles R. Ryrie, Teologia Sistematika,..., 360
} 
Sebelum kematian-Nya, Yesus banyak mengalami penderitaan. Stevri I. Lumintang menuliskan bahwa :

Yesus memahami bahwa pendetiaan-Nya merupakan kenyataan yang Dia harus hadapi, karena itu sesuai dengan penentuan Allah Tritunggal. Ia menderita seumur hidup, penderitaan-Nya adalah total (manusia secara utuh), tubuh dan jiwa. Penderitaan-Nya menjadi lebih unik karena Ia menderita demi menanggung kesalahan semua manusia (semua musuh-Nya). Penderitaan-Nya adalah penderitaan yang menebus, menganti penderitaa orang berdosa yang terpisah dengan Allah (orang berdosa ditinggalkan oleh Allah). Pergantian ini dimengerti dengan seruan Yesus di atas kayu salib: "Eloi-Eloi Lama Sabakhtani", merupakan seruan penebusan, dimana Yesus menganti posisi manusia yang terpisah jauh dari Allah karena dosa (neraka). ${ }^{37}$

Dengan itu, dapat dipahami bahwa penderitaan Yesus adalah suatu proses menuju kematianNya sebagai puncak dari karya penebusan Kristus bagi orang berdosa. Dalam kematian-Nya ada beberapa hal yang perlu diperhatikan seperti : Dia disalibkan tanpa bersalah, kematian-Nya disertai dengan tanda-tanda ajaib (kegelapan, tabir Bait Allah terbelah menjadi dua, terjadi gempa bumi, dan kuburan-kuburan terbuka dan orang kudus yang telah meninggal bangkit), kematianNya telah dinubuatkan, dan sebagainya.

Selain dari uraian di atas, ada aspek-aspek yang sangat penting dalam kematian Yesus Kristus. Aspek-aspek tersebut dapat kategorikan sebagai berikut $:^{38}$

- Pengurbanan (Sacrifice), Yesus merupakan pengenapan hukum taurat, secara simultan Ia sebagai imam dan juga kurban yang tidak bercacat sebab Ia tidak pernah melakukan kesalahan.

- Perdamaian (Propitiation), dengan pengurbanan Yesus maka ada perdamaian antara Allah dan manusia (Rm. 3:25; Ibr. 2:17).

\footnotetext{
${ }^{37}$ Stervi I. Lumintang, Keunikan Theologia Kekristenan, ..., 97-98

${ }^{38}$ Lotnatigor Sihombing, Yesus Kristus Tuhan Kita,..., 66-86
} 
- Pendamaian atau pemulihan (reconciliation), melalui kematian Yesus maka manusia berdosa (ekhtros) telah berubah menjadi ‘yang dikasihi Allah’ (agapetos) melalui darah Yesus Kristus.

- Penebusan (redemption), dengan kematian Yesus maka umat manusia telah di tebus dari belenggu (hamba) dosa dengan harga yang mahal melalui darah yang mengalir di atas kayu salib.

Dengan itu, melalui karya penebusan maka orang percaya akan memperoleh panggilan atau pemilihan Allah, pembenaran, pengudusan, dan kelahiran kembali.

\section{Kebangkitan-Nya}

Kebangkitan Yesus adalah salah satu kebenaran dasar iman Kristen. Kebangkitan Yesus Alkitab memberikan rujukan melalui bukti-bukti seperti, kubur kosong (Mat. 28:6; Mrk. 15:4-45; 16:1; Luk. 24:3, 12; Yoh. 20:1-2). Selain itu, Yesus sendiri menampakan dir-Nya baik kepada Maria Magdalena (Yoh. 20:11-18; Mrk. 16:9), kepada beberapa wanita (Mat. 28:1-10), kepada Petrus (Luk. 24:34), kepada dua murid yang berjalan di Emaus (Luk. 24:13-35), kepada kedua belas murid, kecuali Thomas yang tidak hadir (Luk. 24:36-43; Yoh. 20:10-23), kepada Thomas yang berada di antara keduabelas murid (Yoh. 20:24-29), dan seterusnya.

Kebangkitan Yesus adalah merupakan pengenapan nubuatan dalam PL (Mzm. 2:7; Ibr. 1:5; Kis. 13:33; Mzm. 16:8-11; Kis. 16:2:25-31; Mzm. Yes. 53). Selain itu Yesus sendiri berkali-kali memberitahukan kepada murid-murid-Nya bahwa Ia akan mati dan bangkit (Yoh. 2:19, 21; Mat. 12:40; Mrk. 8:31; Mat. 27:63; Yoh. 10:18). ${ }^{39}$

\footnotetext{
${ }^{39}$ Stevri I. Lumintang, Keunikan Theologi Kristen, ..., 99
} 
Selain itu, kebangkitan Yesus juga membuktikan ke-ilahian-Nya, dan kebangkitan-Nya menjamin bahwa pengorbanan-Nya diterima (Rm. 4:24). Kemudian kebangkitan-Nya juga membuktikan kebangkitan daging.

\section{Kenaikan-Nya}

Setelah Ia bangkit dari kematian-Nya, kemudian Ia menampakkan diri beberapa kali selama empat puluh hari, maka Ia naik ke surga (Mrk. 16:19; Luk. 24:51; Yoh. 3:13; Kis. 7:55-56). Menurut Peter Wongso, kenaikan Yesus penting karena; pertama, tubuh kebangkitan-Nya tidak lagi ditaklukan oleh hukum taurat; kedua, dunia tidak mampu menerima atau menampung tubuh kebangkitan yang tak berdosa itu; ketiga, kenaikan-Nya merupakan penggenapan penebusan umat manusia; keempat, untuk menjadi berita yang kuat bagi para rasul dalam memberitakan Injil; serta kelima, untuk menjadikan-Nya objek penyembahan. ${ }^{40}$

Selain itu, Peter Wongso juga menuturkan bahwa kenaikan Yesus bertujuan untuk menjadi pelopor bagi para pengikut-Nya menuju surga (Ibr. 6:20), Dia juga menyediakan tempat bagi setiap orang percaya (Yoh. 14:2; Ibr. 9;21-24), Ia menyatakan diri-Nya di hadapan Allah Bapa demi jemat-Nya (Ibr. 9:24), dan Ia duduk di sebelah kanan Allah Bapa sebagai khalik dan bumi menanti saat di mana segalanya takluk kepada-Nya. ${ }^{41}$ Dengan itu, kenaikan Yesus sangat penting dalam karya keselamatan umat manusia.

\section{Kedatangan-Nya Kembali}

${ }^{40}$ Peter Wongso, Kristologi, (Malang: Literatur SAAT, 1990), 110-111

${ }^{41}$ Peter Wongso, Kristologi,..., 113-114 
Kedatangan Yesus kembali merupakan janji-Nya kepada umat manusia. Namun mengenai saat dan waktu kedatangan-Nya tak seorang pun yang tahu, hanya Allah Bapa yang mengetahuinya (Mat. 24:36), pada saat yang tak terduga Kristus datang kembali (Mat. 24:44). Kedatangan-Nya kembali dengan tubuh kebangkitan (dilihat secara rohani), da bersifat universal dengan waktu yang bersamaan, serta Ia datang seperti waktu Ia naik ke surga (Kis. 1:11; Mat. 24:30-36; 26:64, dan seterusnya). ${ }^{42}$ Kemudian kedatangan-Nya kembali bersifat penghakiman.

Kedatangan Yesus yang kedua kali mewujudkan kemenangan besar dan akhir atas segala sesuatu. Karena itu, kedatangan-Nya yang kedua kali digambarkan dengan kemuliaan besar (Mat. 24:30; Mrk. 13:36; Luk. 21:27). Kedatangan-Nya kelak menyatakan kemenangan final-Nya atas segala sesuatu, kontras dengan kedatangan-Nya yang pertama dalam kerendahan-Nya.

Dengan demikian, kedatangan-Nya kembali merupakan penggenapan serta penyempurnaan karya penebusan segenap umat manusia menuju kepada kekekalan yang abadi.

\section{$\underline{\text { Simpulan }}$}

Teologia Reformed adalah bukan theologia yang baru tetapi theologia yang sudah berakar jauh sebelumnya, yaitu theologia yang ortodoks atau tradisional. Theologia Reformed dibangun di atas Alkitab sebagai sumber kebenaran dan finalitas kebenaran itu sendiri, serta pengakuan iman dan kredo bapa-bapa gereja.

Pemahaman kaum Reformed mengenai kristologi selalu berangkat dari kesaksian-kesaksian yang diungkapkan oleh Alkitab. Dengan demikian, kaum Reformed mengakui keberadaan Yesus sebelum menjadi manusia (inkarnasi). Yesus memiliki sifat kekekalan, dan memiliki dua natur

\footnotetext{
${ }^{42}$ Ibid, $188-120$
} 
yaitu natur Ilahi dan natur manusia di dalam satu pribadi. Yesus Kristus merupakan final jabatan imam, nabi dalam Perjanjian Lama, serta raja bagi orang percaya juga alam semesta.

Yesus Kristus adalah oknum kedua dari Tritunggal yang berinkarnasi menjadi manusia, demi tujuan Allah Bapa untuk menyelamatkan umat manusia. Hal itu dinyatakan didalam karyaNya baik melalui kelahiran-Nya, kematian-Nya, kebangkitan-Nya, dan kenaikan-Nya. Kemudian Ia akan datang kembali dalam kemenangan dan kemuliaan-Nya. Jadi, Yesus Kristus adalah finalitas jalan menuju kepada kekekalan yaitu keselamatan. Tak ada keselamatan di luar Kristus. 